\title{
PENINGKATAN KEMAMPUAN SISWA DALAM MEMBACA TEKS BAHASA INGGRIS MELALUI PERMAINAN POSTCARD FROM JHON DI KELAS VII MTS.MUHAMMADIYAH 22 PADANGSIDIMPUAN
}

\author{
KHAIRUNNISAH,S.Pd.,M.Hum \\ Universitas Muhammadiyah Tapanuli Selatan (UMTS) Padangsidimpuan
}

\begin{abstract}
ABSTRAK
Latar belakang penelitian ini, karena kurangnya kemampuan siswa dalam membaca teks Bahasa Inggris. Rendahnya kemampuan siswa dalam membaca teks Bahasa Inggris dikarenakan metode ataupun strategi yang digunakan oleh guru masih monoton dengan cara menyuruh siswa membaca teks satu persatu. Hal ini membuat siswa merasa bosan dan juga tidak mengerti apa yang sudah mereka baca. Tujuan penelitian ini memperoleh gambaran tentang seberapa besar peningkatan siswa kelas VII MTS.Muhammadiyah 22 Padangsidimpuan melalui permainan Postcard from Jhon. Metode yang digunakan dalam penelitian ini adalah PTK (Penelitian Tindakan Kelas), dimana penelitian kualitatifnya berupa observasi serta data kuantitatifnya berupa hasil tes dengan cara mendeskripsikan, menganalisa, mengevaluasi dan merefleksikan sehingga didapatkan hasil penelitian yaitu adanya peningkatan kemampuan siswa dalam membaca teks Bahasa Inggris, dengan perolehan nilai siswa dari rata-rata 55 menjadi 80. Kesimpulan akhir dari penelitian ini bahwa, tindakan perbaikan pembelajaran mengakibatkan kemampuan membaca teks Bahasa Inggris siswa kelas VII di MTS.Muhammadiyah 22 Padangsidimpuan sangat tinggi dan menyebabkan efektifitas pembelajaran di kelas VII tersebut sangat tinggi.
\end{abstract}

Kata kunci : membaca, permainan Postcard from Jhon

\section{A. Pendahuluan}

Latar belakang penelitian ini yaitu kegiatan membaca kelihatannya sudah mulai tidak digemari lagi terutama dikalangan pelajar, khususnya dalam keterampilan membaca teks berbahasa Inggris, karena memahami suatu bacaan tidaklah mudah. Seperti salah satu pendapat Brown (2000) yang menyatakan bahwa kita semua sangat

ISSN 2541-3775 bergantung kepada batasan jumlah dan huruf ("In fact, all of us are dependent on some limited number of letters throughout our lives” (Brown, 2000). Hal ini menunjukkan kenapa kemampuan membaca dalam Bahasa asing khususnya bahasa Inggris dianggap sebagai hal yang paling penting di tingkat internasional bagi setiap orang. 
Kesulitan dalam membaca juga dirasakan oleh pelajar di kelas VII MTS.Muhammadiyah 22 Padangsidimpuan, dilihat dari perolehan nilai di keterampilan membaca masih tergolong rendah terutama dalam membaca teks bahasa Inggris. Di tingkat SMP/MTS sederajat, Bahasa Inggris adalah salah satu mata pelajaran yang diujikan pada Ujian Akhir Nasional. Dari soal-soal tes tersebut, sekitar $40 \%$ adalah tes membaca. Dari hasil observasi awal, para pelajar di kelas VII MTS.Muhammadiyah 22 Padangsidimpuan masih banyak yang belum tuntas dalam keterampilan membaca teks Bahasa Inggris. Hal ini disebabkan karena kurangnya ketertarikan para siswa dalam membaca teks Bahasa Inggris.

Keterampilan membaca teks Bahasa Inggris yang harus dikuasai para pelajar tersebut yaitu, keterampilan memahami teks, menguasai kosa kata (vocabulary), menentukan topik dan ide utama dari suatu teks. Untuk mengatasi masalah ini, para pengajar ataupun guru harus menentukan metode yang paling efektif dalam mengajarkan keterampilan membaca teks berbahasa Inggris untuk para pelajar kelas VII MTS.Muhammadiyah 22Padangsidimpuan. Untuk membuat keterampilan membaca teks berbahasa Inggris lebih dibutuhkan dan diminati oleh para siswa, maka, para pengajar harus menentukan langkah- langkah dalam meningkatkan keterampilan membaca. Salah satu upaya yang harus dilakukan para pengajar untuk meningkatkan keterampilan siswa dalam membaca teks berbahasa Inggris adalah dengan menarik minat siswa menggunakan media permainan "post card from Jhon". Berdasarkan latar belakang masalah dan rumusan masalah di atas, dalam penelitian ini dibatasi yaitu peningkatan keterampilan membaca teks bahasa inggris dan metode permainan yang digunakan adalah Postcard fromJohn. Adapun tingkatan yang akan diteliti adalah kelas VII MTS.Muhammadiyah 22 Padangsidimpuan. Hal pertama yang akan diteliti adalah metode postcard from John dalam meningkatkan keterampilan membaca. Dan kedua adalah peningkatan keterampilan membaca siswa dalam Bahasa Inggris menggunakan metode permainan postcard from John. Maka, dari penjelasan di atas penulis merumuskan masalah dalam penelitian ini yakni Bagaimana peningkatan keterampilan siswa dalam membaca Bahasa Inggris dengan menggunakan metode permainan Postcard from John?

\section{B. Deskripsi Teori}

Pada dasarnya, membaca adalah kemampuan memahami sebuah tulisan 
bahasa secara sederhana, dalam hal ini bahasa yang dimaksud adalah bahasa inggris. Oleh karena itu, mengimplementasikan keterampilan membaca lebih difokuskan daripada pengetahuan dasar.

Johnson (2008) berpendapat bahwa membaca adalah sebuah keterampilan yang konstan, seperti beberapa keterampilan dia memperoleh keterampilan membaca melalui praktek. Sebagai akibatnya, jika kita tidak melatih, kita tidak akan mendapatkan keterampilan yang lebih baik dan mungkin juga merosot ("Reading is a constantly developing skill. Like any skill, he get better at reading by practicing. And conversely, if we do not practice, he will not get better and our skill may deteriorate." (Johnson 2008:4).

Dari penjelasan di atas dapat ditarik kesimpulan bahwa keterampilan membaca adalah suatu keterampilan yang harus terus dikembangkan dan dikuasai dengan cara selalu berlatih, terutama dalam membaca teks bahasa Inggris yang sangat memerlukan pemahaman mendalam dan penguasaan kosa kata.

Selain itu, Anderson (2007:2) berpendapat bahwa pemahaman membaca adalah proses membangun makna dengan mengganbungkan beberapa proses komplek kata, kata dan pengetahuan dunia, dan kelancaran (Reading comprehension is the process of constructing meaning by coordinating a number of complex processes that include word reading, word and world knowledge, and fluency). Dengan kata lain, keterampilan membaca merupakan proses interaktif yang menggabungkan antara pengetahuan pembaca dan informasi dari teks.

Kegiatan membaca meliputi 3 keterampilan dasar yaitu recording, decoding, dan meaning. Recording merujuk pada kata-kata dan kalimat, kemudian mengasosiakannya dengan bunyi-bunyinya sesuai dengan sistem tulisan yang digunakan. Proses decoding merujuk pada proses penerjemahan rangkaian grafis ke dalam kata-kata. Sedangkan meaning merupakan proses memahami makna yang berlangsung dari tingkat pemahaman, pemahaman interpretatif, kreatif, dan evaluatif. Proses recording dan decoding berlangsung pada siswa kelas awal, sedangkan meaning lebih ditekankan pada kelas tinggi (Farida Rahim, 2008: 2). Samsu Somadayo (2011: 4) mengungkapkan bahwa membaca adalah suatu kegiatan interaktif untuk memetik serta memahami arti yang terkandung di dalam bahan tulis. 
Dari beberapa pendapat di atas dapat disimpulkan bahwa membaca adalah proses pengasosiaan huruf, penerjemahan, dan pemahaman makna isi bacaan.

Kegiatan membaca akan lebih menarik jika dikolaborasi dengan menggunakan permainan. Bermain adalah pekerjaan yang masih digemari oleh para pelajar dan ini berkontribusi kepada semua aspek perkembangan. Melalui bermain, para siswa menstimulasi inderanya, belajar bagaimana menggunakan ototnya, mengkoordinasikan penglihatan dengan gerakan, meningkatkan kemampuan tubuhnya dan mendapatkan keterampilan baru. Melalui bermain, mereka mencoba untuk bermain peran, mengatasi perasaan yang tidak nyaman, memperoleh pengertian dari pandangan orang lain, dan membangun gambaran dari dunia sosial. Murid mengembangkan keterampilan pemecahan masalah, mengalami kegembiraan dalam berkreatifitas, dan menjadi cakap dalam berbahasa.

Dalam penelitian ini, peneliti memilih permainan Postcard from Jhon dalam meningkatkan kemampuan siswa dalam membaca teks Bahasa Inggris. Metode Postcard from Jhon ini adalah suatu kegiatan yang menuntut siswa untuk membaca teks berbahasa Inggris serta memahaminya. ISSN 2541-3775
Adapun langkah-langkah yang dilakukan dalam metode bermain dengan menggunakan Postcard from John ini sebagai berikut :

\section{Jenis aktivitas}

Seluruh siswa ikut serta dengan sistem pairwork menceritakan kembali beritaberita dari sebuah postcard dan kemudian setiap tim menceritakan kembali berita yang di dapatkan dari postcard tersebut dan kemudian membuat plot perjalanan pada peta yang sudah disediakan sebelumnya.

\section{Materi Permainan}

Texts: A Delhi; B Kathmandu 1;

C Kathmandu 2; D Calcutta; E

Mandalay; F Chiang Mai; G Hong

Kong; H Bali; I Sydney Route map

\section{Kegiatan}

Mendeskripsikan setiap pemandangan atau temapat dan kejadian yang sudah lewat.

\section{Structures}

Past tenses, present perfect, present simple and continuous

\section{Lexical areas}

Perjalanan turis, pemandangan, kota, dll.

\section{Metode}

Metode yang dipakai yaitu Penelitian Tindakan Kelas. Prosedur yang dilakukan dalampenelitian ini meliputi perencanaan, Vol.3 No.1 Januari - Juni 2018/57 
pelaksanaan tindakan, observasi, evaluasi/refleksi tahap pertama, kemudian dilakukan kembali di siklus kedua apabila siklus pertama tidak berhasil.

Langkah perencanaan meliputi, guru menyusun rencana pembelajaran Bahasa Inggris untuk kelas VII semester II dengan alokasi waktu 2 x40 menit. Rencana pengajaran berupa kompetensi dasar, hasil belajar dan indikator, langkah pembelajaran, sarana dan sumber serta evaluasi. peneliti menentukan fokus observasi dan aspekaspek yang diamati baik yang berkaitan dengan kegiatan sisa, kegiatan guru maupun interaksinya dalam kegiatan belajar mengajar.

Pelaksanaan tindakan meliputi, guru mengkondisikan kelas dan menyampaiakn tujuan pembelajaran serta menjelaskan teks Bahasa Inggris dengan menggunakan alat permainan postcard from Jhon. Siswa secara kelompok disuruh membacakan kartu yang berisi perjalanan Jhon dengan dibantu peta. Setiap grup berdiskusi dan menyesuaikan kartu dengan peta. Selain itu guru juga menjelaskan tentang tenses yang digunakan dalam teks tersebut.siswa maupun kelompok siswa diharapakan mampu mengidentifikasi tenses yang ada sehingga mampu menceritakan kembali rute perjalanan sesuai yang sudah disediakan dengan menggunakan tenses yang tepat. Akhir kegiatan, siswa diberi tugas mengerjakan soal essay. Tindakan tersebut dilakukan baik pada siklus pertama maupun kedua. Tindakan siklus kedua sebagai langkah perbaikan dari siklus pertama.

Observasi terhadap kegiatan guru, kegiatan siswa dan proses pembelajaran dilaksanakan teman sejawat dengan mengacu pada lembar observasi, kemudian observasi proses belajar siswa juga dilakukan guru sambil mengajar.

Evaluasi dan refleksi terhadap pelaksanaan tindakan dilakukan guru dan teman sejawat, didasarkan pada hasil observasi dan nilai tes siswa. Refleski terhadap pelaksanaan tindakan dilakukan berdasarkan hasil evaluasi dan hal-hal yang unik terjadi di kelas, dilaksanakan guru dan teman sejawat. Hasil refleksi siklus pertama menjadi dasar untuk rencana dan tindakan sikulus kedua.

Hasil penelitian tindakan kelas siklus 1 dan 2 serta temuannya dirumuskan kemudian dilakukan pembahasan. Secara rinci hasil penelitian untuk setiap siklus dideskripsikan, dianalisis, dan direfleksikan. Setelah hasil penelitian dirumuskan kemudian melaksanakan dan merumuskan diskusi hasil penelitian. Penelitian dilakukan selama 3 bulan, mulai bulan februari sampai 
bulan mei 2018. Tempat penelitian dilaksanakan di MTSS.Muhammadiyah 22 Padangsidimpuan.

\section{Pembahasan}

Hasil penelitian menunjukkan bahwa terjadi peningkatan nilai rata-rata membaca teks Bahasa Inggris siswa kelas VII MTS.Muhammadiyah 22 Padangsidimpuan akibat tindakan melalui permainan postcard from Jhon. Rata-rata siswa mengalami peningkatan nilai dari 80 siklus ke 1 dan nilai 90 siklus ke 2. Besarnya rata-rata untuk dua siklus dapat dilihat pada grafik di bawah ini.

\section{Grafik 1}

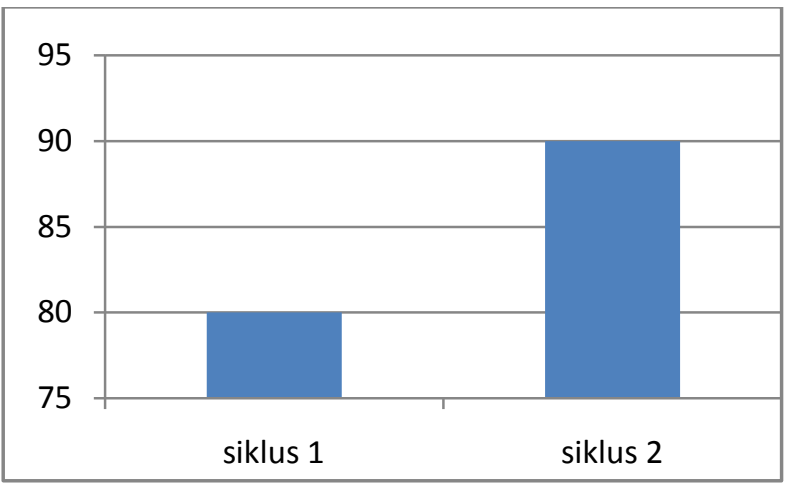

Selain ditinjau dari nilai rata-rata, peningkatan tindakan perbaikan pembelajaran dapat pula dilihat dari persentase peningkatan jumlah siswa yang gagal (nilai <75). Dari data awal sebelum tindakan perbaikan, sesuai yang tertulis dalam latar belakang masalah adalah sejumlah 40 siswa. Sementara itu setelah dilakukan tindakan perbaikan pembelajaran siklus pertama dan siklus kedua mengalami peningkatan menjadi 90. Secara jelas besarnya persentase peningkatan pembelajaran untuk jumlah siswa yang dikategori bisa, terlihat dari grafik di bawah ini.

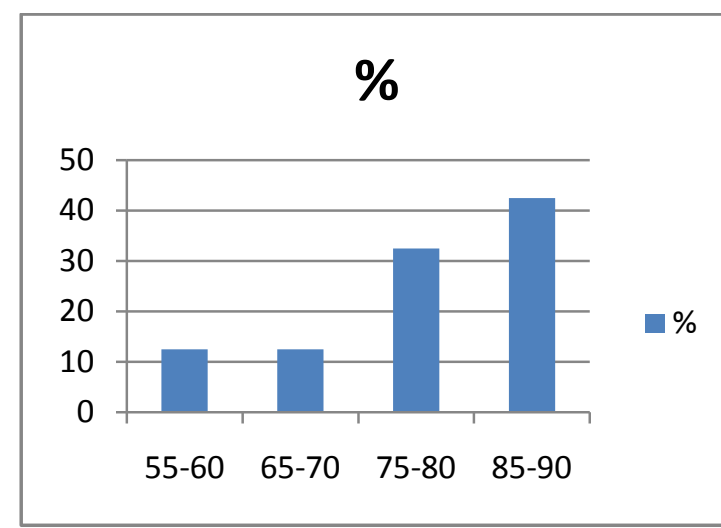

Grafik 2 menunjukkan bahwa penerapan metode permainan postcard from Jhon yang dilaksanakan guru dapat meningkatkan kemampuan siswa dalam membaca teks Bahasa Inggris.

Ditinjau dari data kualitatif, hampir seluruh siswa pada pembelajaran permainan postcard from Jhon menunjukkan bahwa adanya minat membaca tinggi, sangat antusias, bersemangat aktif, kreatif, suasana belajar kondusif bergairah dan saling ingin paling cepat menyelesaikan tugasnya, menyenangkan dengan hasil belajar yang sangat memuaskan, guru dapat menciptakan suasana belajar yang menyenangkan, berfungsi sebagai fasilitator dengan salah Vol.3 No.1 Januari - Juni 2018/59 
satunya menyediakan 3 set alat peraga permainan postcard from Jhon;sebagai moderator dengan cara pembagian kelompok belajar siswa dan mengatur belajar siswa dalam kelompok maupun perorangan. Kegiatan interaksi pembelajaran dapat diciptakan guru secara multi interaksi, baik interaksi antara sisa dalam kelompok interaksi antar kelompok siswa dengan guru, individu maupun interaksi siswa dengan alat peraga. Proses pembelajaran menunjukkan efektifitas pembelajaran permainan permainan postcard from Jhon di kelas VII MTS.Muhammadiyah 22 Padangsidimpuan.

Hal unik yang dapat ditemukan dalam penelitian ini antara lain : 1) Dari segi siswa, dalam proses penggunaan alat peraga terjadi saling mendahului dalam membaca postcard dan juga peta yang disediakan. Selain itu para siswa berebutan dalam memberikan komentar dan membacakan berita yang ada di masing-masing postcard, sehingga menimbulkan sedikit kegaduhan di ruangan kelas. 2) Dari segi guru, guru masih kesulitan mengatasi keadaan berdesakan dan kegaduhan dalam suasana belajar. Guru dituntut mengatur belajar kelompok kecil dan keterampilan mengelola kelas sehingga dapat mengatasi keadaan gaduh tanpa menghilangkan kondisi bergairah, antusias dan kondisi kompetitif antara siswa.

\section{E. Kesimpulan dan Saran}

Dari penelitian ini dapat disimpulkan bahwa besar peningkatan kemampuan membaca teks Bahasa Inggris setelah dilakukan tindakan perbaikan pembelajaran melaui permainan postcard from Jhon di kelas VII MTS.Muhammadiyah 22 Padangsidimpuan, rata-rata meningkat menjadi sebesar 80 dan 90. Siswa yang memperoleh nilai 75 ke atas yang dikategorikan bisa mencapai $90 \%$. Tindakan perbaikan pembelajaran mengakibatkan kemampuan membaca teks Bahasa Inggris siswa MTS.Muhammadiyah Padangsidimpuan sangat tinggi. Proses perbaikan pembelajaran dengan menerapkan metode permainan permainan postcard from Jhon ditinjau dari kegiatan siswa, kegiatan guru dan interaksinya menyebabkan efektifitas pembelajaran di kelas VII MTS.Muhammadiyah 22 Padangsidimpuan sangat efektif.

Saran yang dapat disampaikan dalam penelitian ini, yakni metode permainan permainan postcard from Jhon sebagai salah satu metode yang telah teruji sangat efektif pada pembelajaran Bahasa Inggris perlu disosialisasikan dan diimplementasikan kepada siswa lainnya, khususnya dalam materi membaca teks Bahasa Inggris. Pihak sekolah perlu mendukung dan membantu 
guru dalam menyiapkan alat peraga permainan permainan postcard from Jhon, sehingga jumlah dan variasi alat peraga dapat terpenuhi sesuai keperluan siswa. Kreatifitas dan inovasi guru dalam penggunaan metode dan alat peraga pembelajaran perlu secara terus menerus dibangkitkan, seiring dengan dinamika perkembangan siswanya.

\section{F.Daftar Pustaka}

Anderson. 2007. Reading Comprehension. London. Longman.

Hadfield, Jill and Charles.2008. Reading Games (Photocopiable ELT Games and Activities). London : Longman

Henry, Guntur Tarigan. (2008). Membaca Sebagai Suatu Keterampilan Berbahasa. Bandung: Angkasa.

Johnson, Andrew, P. (2008). Teaching Reading and Writing. America: British Library.

Pramila Ahuja dan G.C. Ahuja. (2010). Membaca ecara Efektif dan Efisien. Bandung: Kiblat Buku Utama.

Rahim, Farida.(2008). Pengajaran Membaca di Sekolah Dasar. Jakarta : Bumi Aksara

Somadayo, Samsu. (2011). Strategi dan Tehnik Pembelajaran
Membaca. Yogyakarta : Graha Ilmu.

Suyatmi.(2000). Membaca

I. Surakarta:UNS

Press.(http://id.wikipedia.org/wiki/Kema mpuan diakses tanggal 22 Desember 2017).

Yunus, Abidin. (2012). Pembelajaran

Membaca Berbasis Pendidikan Karakter. Bandung: Refika Aditama.. 